専門医症例報告

外傷後の上顎前歯部欠損に骨造成術を併用してインプラント治療を行った症例 園山亘

\title{
Prosthetic Rehabilitation of a Patient with Missing Maxillary Incisors caused by a Traffic Accident, using Autogenous Bone Graft and Implant-supported Fixed Partial Denture
}

\section{Wataru Sonoyama}

抄 録

症例の概要：患者は 25 歳の男性で, 外傷により生じた前歯部欠損による発音障害と審美傷害を主訴に来 院した．同欠損には受傷後に可撤性床義歯が作製されていたが，違和感が強く，使用していなかった。 損部顎堤は唇舌的な萎縮が認められたため, 骨造成術を併用したインプラント治療を行い, 機能回復を行っ た.

考察：機能回復後は定期的なリコールを行っている. 上部構造体基底面にしばしばプラークの停滞を認め るが，インプラント体周囲の炎症や進行性の骨吸収はなく，良好に経過している．アンケートによる口腔 関連 QOL 評価でも高い評価を得ている.

結論：本症例は若い男性であり，固定性補綴装置で機能回復を行うことで高い満足が得られた。

和文キーワード

インプラント補綴，外傷，骨造成，固定性補綴装置，口腔関連 QOL

\section{ABSTRACT}

Patient: The patient was a 25-year-old male with missing maxillary incisors caused by injury, who had problems in pronunciation and esthetics related to the edentulous space. Removable partial denture was made against the edentulous space in past, but it was not used due to incompatibilities. Autogenous bone graft was carried out to recover bone atrophy, and a implant-supported denture was inserted.

Discussion: Although accumulated dental plaque was sometimes found, signs of inflammation or progressive bone resorption was not found around implant fixtures during periodical recall. Oral conditionrelated quality of life (QOL) was evaluated by a self-administered QOL questionnaire, and it was revealed that the patient's oral condition-related QOL was improved after the insertion of an implant-supported fixed prosthesis.

Conclusion: With an autogenous bone graft to the anterior atrophic maxilla, implant-supported fixed prosthesis could improve patients' QOL.

\section{Key words}

implant prosthodontics, injury, bone augmentation, fixed prosthesis, oral condition-related quality of life (QOL)

岡山大学医学部・歯学部附属病院＼cjkstart補綴科（クラウンブリッジ）

Department of Fixed Prosthodontics, Okayama University Hospital of Medicine and Dentistry

受付 : 2007 年 11 月 15 日/受理 : 2008 年 10 月 5 日

Received on November 15, 2007/Accepted on October 5, 2008 


\section{I 。緒言}

歯の欠損に起因する機能障害を回復する手段として インプラント治療は有効な選択肢のひとつであること が明らかとなっている。特に若年者においては固定性の 補綴装置で機能回復を行えることで，その QOL の向上 に大きく貢献できる場合が多い，本症例では 25 歳男性 の上顎前歯部の欠損に対してインプラント支持の固定 性補経装置を装着し機能回復を図り，処置後 7 年の経 過を観察したので報告する。

\section{II . 症例の概要}

患者：初診時年齢 25 歳，男性

初診：1996 年 8 月

主訴：下顎左側臼歯部の冷水痛，上顎前歯部について の治療相談

現病歴：1991 年 10 月に自転車で走行中に転倒し, 21|1 を喪失した。他院での応急処置後，欠損による審 美障害と発音障害を主訴に同年 11 月に本院を受診した。 同年 12 月に当科にて可撤性金属床義歯を作製，装着し た。義歯は取り外しが煩わしく，違和感が強いため使用 できなかったが，他の処置法があると知らなかったため 放置していた。平成 1996 年 7 月頃より下顎左側臼歯部 に冷水痛を覚えたため来院した，あわせて上顎前歯部欠 損の治療法に関しての説明を希望していた。

既往歴: 公立病院精神科に不眠のため通院中（レンド ルミン $0.25 \mathrm{mg}$ を眠前に服用. 意思の疎通や外科的処置 に問題はない)，その他の特記事項はない.

現症：21|1 が欠損しており，両側隣在歯は健全歯で あった。アングル III 級咬合で，側方運動時のガイドは グループファンクションであった。 欠損部顎堤の上下的 な吸収は軽度であるが，唇側には外傷に起因すると思わ れる大きい骨吸収があった。 欠損部から息が漏れること による発音障害があった。歯周状態は深いポケットもな く良好であるが，プラークコントロールは不良で，辺縁 歯肉に軽度の炎症が認められた。 カリエスアクティビ ティは低くなく，補綴処置に際しては注意が必要である と推測された（図 1).

診断：上顎前歯部欠損による審美障害・発音障害

治療計画の立案 : 患者は過去に可撤性義歯を用いての 補綴処置を受けているものの，着脱の煩わしさ，クラス プや床による違和感と発音障害により全く使用してい なかった。また患者は 25 歳と若いこともあり，可撤性 義歯に対するネガティブなイメージが強く，固定性補綴

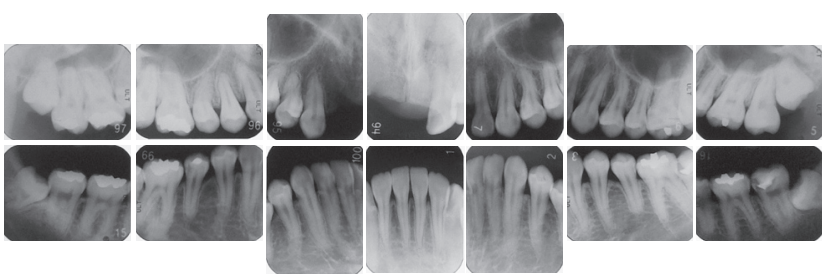

図 1 Dental radiographs at the first visit 初診時デンタル X 線写真

装置による機能回復を強く望んでいた。この患者背景を 考えると本欠損に対する機能回復法として固定性ブ リッジとインプラントが考えられた。両治療法に関する 一般的な特徵に加え，患者に特化した以下の情報を説明 用の模型を用いて提示した。

(1)固定性ブリッジ

隣在歯の歯周状態は良好であり，3|23 を支台とする ことで固定性ブリッジの作製が可能である，支台歯予定 歯はすべて切端咬合であり，接着リテーナーを支台装置 とすれば, ほぼチャネルのみの形成で対応できる.プラー クコントロールが不良であるため, エナメル質を切削し 支台装置を装着することで支台歯がカリエスになりや すくなる可能性がある。

(2)インプラント

健全歯である両側隣在歯を切削することなく，機能回 復が可能である．欠損部唇側の骨吸収が大きいため，イ ンプラント体埋入に先立っての唇側への骨造成が必要 になる可能性が高い. 上下的な吸収については予後が不 透明であるため骨造成は行わない。よって，上部構造は ボーンアンカードブリッジタイプとなる.

治療方針の決定 : 患者は隣接する欠損の機能回復のた めに, 健全歯を切削することに大きな抵抗を感じており, インプラント義歯による機能回復を強く希望した。した がって，以下の治療計画を立案した。

\#1 断層 X 線撮影による欠損部の骨の幅径の診査

\#2 必要であれば唇側骨欠損に対する水平的な骨 造成の施術

\#3 インプラント支持のボーンアンカードブリッ ジによる機能回復

\#4 メインテナンス

1997 年 4 月にステントを装着しての断層 X 線写真撮 影を行った（図 $2 \mathrm{~A}$ )。その結果をもとに, 当院口腔外 科医とカンファレンスを行い，オトガイ部からの骨移植 を併用した骨造成が必要であること，骨造成後に $1 \mid 1$ 相 当部にインプラント体を 2 本埋入予定とすることを確 認した。この方針を患者に提示し,同意を得た。しかし， 

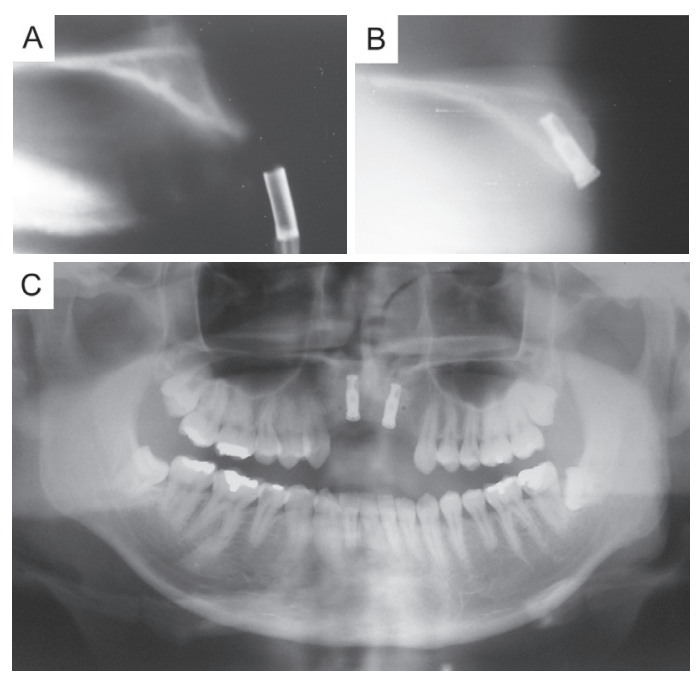

図 2 Radiographic examination before and after implant fixture placement: (A) A tomogram before bone augmentation, (B) A tomogram after implant fixture placement, (C) Panoramic radiograph after implant fixture placement インプラント体埋入前後のX線診査：（A）骨移 植前断層 X 線写真，（B）インプラント体埋入後 断層 $\mathrm{X}$ 線写真, ( C ) インプラント体埋入後パノ ラマ X 線写真
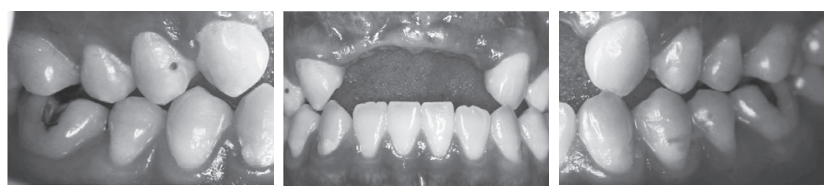

図 3 Intraoral views before prosthodontic treatment 処置開始前の口腔内写真

1997 年 5 月に交通事故に遭い 2 を喪失した（図 3 ). そのため，上部構造を 2 部まで延長し対応する治療方 針に変更し，同意を得たため，以降の処置を進めていく こととなった。

\section{III．治療内容と経過}

1997 年 7 月 : オトガイ部からの骨移植を併用した骨 造成を施術した。

1998 年 4 月 : 移植骨を固定したチタン製ピンの除去 と同時に Brånemark Mark II self-tap fixture（直径;3.75 $\mathrm{mm}$, 長さ; $11.5 \mathrm{~mm}$ ) を $1 \mid 1$ 相当部に 2 本埋入した（図 $2 \mathrm{~B}, \mathrm{C})$.

1998 年 12 月：骨造成部位への埋入であるため通法 よりも長い 8 力月の治癒期間を設定した後, 二次手術 を行った。
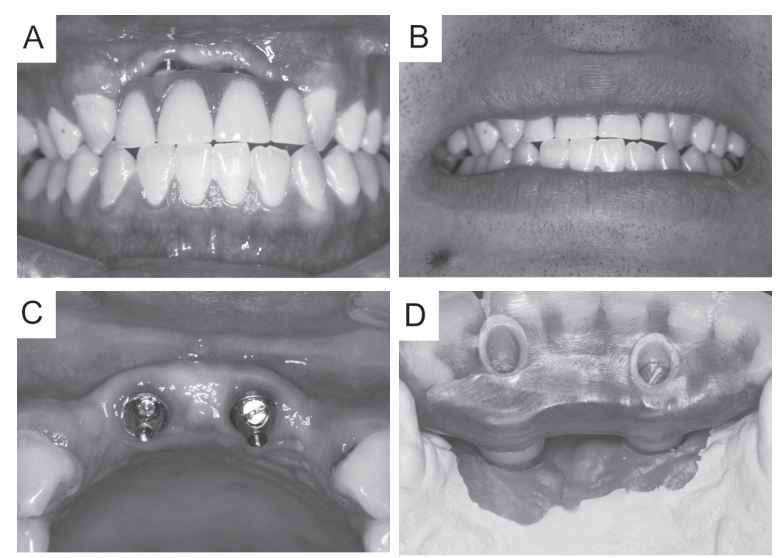

図 4 Intraoral views just after the provisional restoration was inserted

プロビジョナルレストレーション装着直後の口腔 内写真
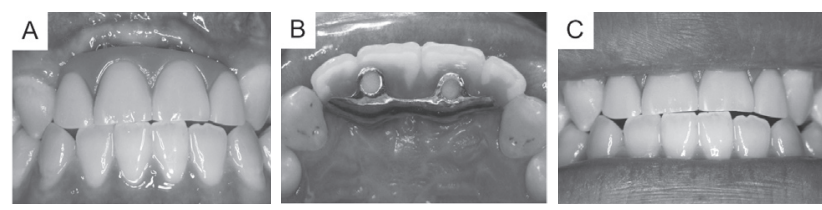

図 5 Intraoral views just after the final prosthesis was inserted

ファイナルレストレーション装着直後の口腔内写真

1999 年 2 月 : ボーンアンカードブリッジタイプのプ ロビジョナルレストレーションを装着した（図 4)。こ の後, 衛生士による TBI と, 衛生士・技工士の意見を 取り入れた形態修正を行った。

2000 年 5 月 : プロビジョナルレストレーションの情 報を取り入れたファイナルレストレーションを装着し た(図 5).

ファイナルレストレーション装着後, 期間の開くこと もあったが，ほぼ半年に 1 度のリコールを行い現在に 至る。上部構造装着から 7 年 2 力月経過したが (図 6), インプラント周囲の進行性の骨吸収もなく（図 7), 良 好に経過している. 現在，人工歯の切端に咬耗が見られ るのみで，リコール期間を通じて，アバットメント周囲 歯肉に炎症所見は見られず, スクリューのゆるみもない.

\section{IV. 考察}

顎堤の上下的な吸収が若干ではあるが認められたた め，ボーンアンカードブリッジタイプの上部構造とした ことで, 息漏孔を中心とする発音障害の回復と, 自浄性・ 清掃性の両立に苦慮した。プロビジョナルレストレー 

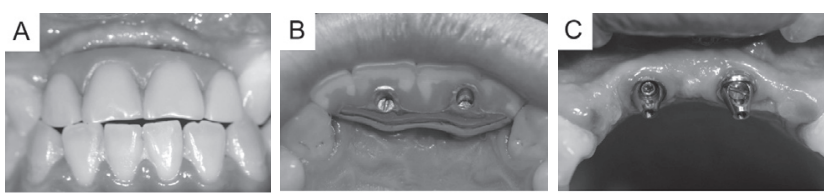

図 6 Intraoral views at 7 years after the final prosthesis was inserted

ファイナルレストレーション装着後 7 年経過時の 口腔内写真
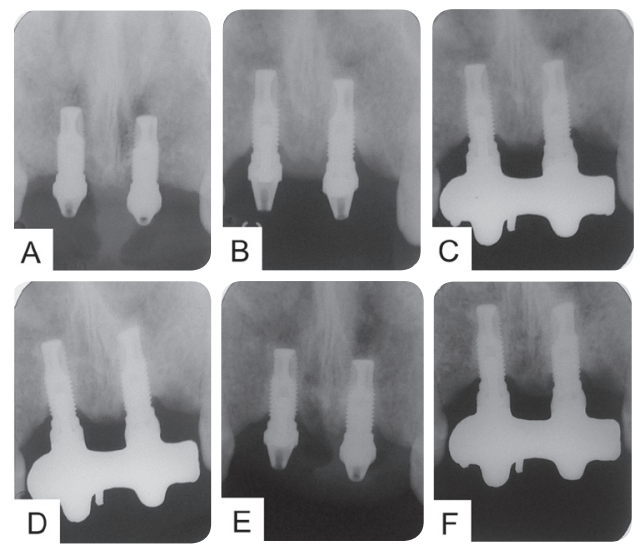

図 7 Dental radiographs at each visit: (A) at abutment connection, (B) 6 months, (C) 14 months, (D) 28 months, (E) 42 months, (F) 85 months after the final prosthesis was inserted 経過観察時のデンタルX線写真：(A) アバットメ ント連結時, (B) 治療終了後 6 力月, (C) 治療終 了後 14 力月，(D) 治療終了後 28 力月，（E）治 療終了後 42 力月, $(\mathrm{F})$ 治療終了後 85 力月

ション装着当初は上部構造基底面と粘膜の間隙から息 が漏れて発音しづらいことを訴えていたものの，数回の 形態修正でこの間隙を縮小し, 改善した。この際には清 掃性とのバランスを考元, 衛生士による TBI と, 衛生士・ 技工士の意見を取り入れた。修正後のプロビジョナルレ ストレーションの情報を取り入れることでファイナル レストレーション装着後の清掃状態に問題はなかった。 しかし，現在ではしばしば上部構造基底面にプラークの 停滞を認めるようになった。今後も時期を見ての動機付 けを行い，全顎的なプラークコントロールを含めた継続 管理が必要である。

自己記入式の QOL 評価 ${ }^{1,2)}$ においては，日常生活関 連 QOL，口腔関連 QOL ともに大きな改善が認められ

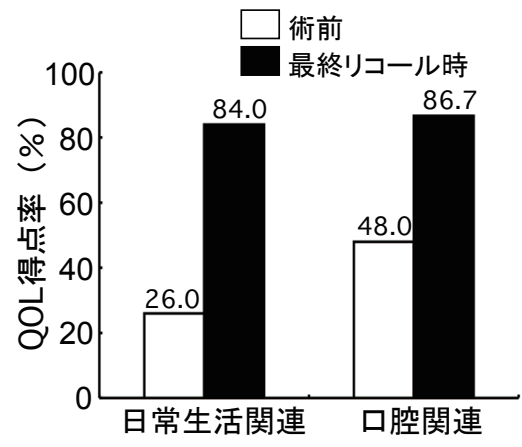

図 8 QOL assessment with self-administered QOL questionnaire

自己記入式のアンケートによる QOL 評価

ている（図 8)。この術後の口腔関連 QOL の得点率は, 当科において少数歯中間欠損を接着ブリッジやインプ ラントで機能回復した患者の平均得点率（接着ブリッジ 群；87.1 \pm 12.3 ，インプラント義歯群；87.8 \pm 9.5）と 遜色のないものであった ${ }^{2)}$.

\section{V. 結 論}

外傷による前歯部欠損に対し，骨造成術を併用してイ ンプラント治療を行うことで，患者の高い満足が得られ た．固定性であり，隣在歯を切削することなく機能回復 を行えるインプラント治療の有用性が確認された。

\section{文献}

1）岡本壮一郎，鈴木秀典，完山 学ほか. 欠損歯列を有 する患者に対する QOL 評価質問表の信頼性・妥当性の 検討. 補綴誌 1999; 43: 698-705.

2) Sonoyama W, Kuboki T, Okamoto S et al. Quality of life assessment in patients with implant-supported and resin-bonded fixed prosthesis for bounded edentulous spaces. Clin Oral Implants Res 2002; 13: 359-364.

\footnotetext{
著者連絡先 : 園山 亘

干 700-8525 岡山市鹿田町 2-5-1

TEL : 086-235-6682

FAX : 086-235-6684

E-mail : wataru@md.okayama-u.ac.jp
} 